\title{
«Jeg er norsk læge» - et sitat med eget liv
}

\author{
«Jeg er norsk læge, sa han enkelt, og mengden vek til side.» Det mest berømte sitat som noen gang er tillagt \\ en norsk lege stammer fra kriminalforfatteren $\emptyset$ vre Richter Frichs romanserie om kirurgen Jonas Fjeld. Sitatet \\ er gjengitt i en rekke varianter, både av forfatteren selv og av flere andre, men finnes faktisk ikke i denne formen \\ i Frichs bøker. Vi mener det er på sin plass å gi en forklaring på det som er blitt et stående uttrykk.
}

\section{Ole Didrik Lærum \\ ole.laerum@gades.uib.no \\ Bergen}

Ragnar Stien

Oslo

Erlend Hem

Tidsskriftet

Øvre Richter Frich (1872-1945) studerte jus og medisin i en kort periode i begynnelsen av 1890-årene før han ble journalist, stjernereporter fra mange himmelstrøk og til slutt heltids forfatter av krim- og røverromaner (1). Han ble en av mellomkrigstidens mest leste spenningsforfattere i Norge. I alt skrev han over 50 bøker, solgte minst to millioner eksemplarer og ble oversatt til ni språk (1). «Den blonde kjempe» dr. Jonas Fjeld er helt og hovedperson i 21 bøker. Bøkene ble utgitt over en periode på nesten 25 år. Den første romanen, De knyttede noever, kom i 1911, og den siste, Menneskejegerne, i 1935.

Fjeld er trolig modellert etter to av Frichs medisinske studiekamerater og venner fra Norske Studenters Roklubb: Olaf Tandberg (1879-1932) og Nikolai Nissen Paus (1877-1956). Begge vennene ble kirurger, Tandberg på Lillehammer og Paus i Tønsberg. Tandberg fikk Frichs bok Olympieren (1924) dedisert til seg (2). Paus, også kalt «Sterke-Paus», var en veltrent turner og pleide etter langvarige og vanskelige operasjoner å hoppe opp og spasere på hendene ut av operasjonssalen når de endelig var ferdige. I tillegg har nok dr. Fjeld trekk fra forfatteren selv. Frich var usedvanlig røslig og grovbygd og drev med boksing i ungdommen. Hans stilige bror, overlegen ved Modum Bad Olaf Henrik Frich (1863-1935), kan også ha bidratt med enkelte trekk $(2,3)$.

Som helteskikkelse var Jonas Fjeld egentlig nokså kamuflert. Han var høy, blond og muskuløs og arbeidet til daglig som en høyt respektert kirurg ved Rikshospitalet og Røde Kors-klinikken i datidens Kristiania. Men i det skjulte bekjemper denne blonde atleten både anarkister, sosialister, kommunister og skumle forbrytere.
I tillegg til Norge strekker virksomhetsområdet hans seg langt, fra Storbritannia og andre europeiske land helt til de mest eksotiske land i Sør-Amerika. Dessuten redder han hele lands befolkninger fra de frykteligste farer fra skruppelløse skurker, og spesielt berger han vakre kvinner fra lumske personer. Motivene bak denne virksomheten er egentlig ganske aktverdige, mens det er mindre bra at han startet denne karrieren ved å begå et bankran. Ranet forblir uoppklart, og derved har han startkapital til å bli en internasjonal forbryterjeger (2).

Frichs nedlatende holdning til andre mennesketyper enn den nordiske blonde rasen, som gjenfinnes i mange av bøkene, har vært mye omtalt (2-4), men privatpersonen Frich var et uttalt apolitisk menneske, uten partieller foreningstilhørighet av noe slag (1).

\section{Et sitat i mange varianter}

I den første litteraturhistorien om norsk kriminallitteratur skrev journalisten Bjørn Carling (1919-2005) i 1976 om Jonas Fjeld: «Lesernes hjerter svulmet når 'den høie, blonde nordmand' banet seg frem til begivenhetenes midtpunkt og rolig sa: 'Jeg er norsk lege. Mit navn er doktor Jonas Fjeld.'» (4, s. 74). Men Carling oppgir ingen referanse.

I 1992 skrev en av oss (ODL) artikkelen Legen som kunstner (5). Her er sitatet gjengitt slik: «Jeg er norsk læge, sa han enkelt, og mengden vek til side». Dette hadde ODL den gang fătt bekreftet av professor i litteraturhistorie Willy Dahl (f. 1927), ekspert på kriminallitteratur og med interesse for Frichs forfatterskap (Willy Dahl, personlig meddelelse). Denne versjonen av sitatet er mye brukt (6-8).

Øvre Richter Frichs biograf, Christopher Hals Gylseth, skrev følgende i et forord til en nyutgave av De knyttede noever (9): «Men hvem er så denne høyreiste, blonde doktor - denne legendariske nordmann som i en serie på 21 romaner brøytet seg frem over alt i verden, med den sedvanlige, bryske kommentar: 'Mitt navn er Jonas Fjeld. Jeg er norsk lege!'» Heller ikke Gylseth gir noen referanse. Gylseths Frichbiografi inneholder denne fremstillingen - også uten referanse: «Lenge før James Bond overhodet var påtenkt, brøytet den kjempestore nordmann seg frem i verden, med sin bryske kommentar: 'Mitt navn er Jonas Fjeld. Jeg er lege!'» (2, s. 12).

I anledning Legeforeningens 100-årsjubileum i 1986 ble det satset på en annonsekampanje. I løpet av en toukersperiode ble $i$ alt fem helsides annonser rykket inn $i$ landets to største aviser, Aftenposten og VG. En av annonsene hadde overskriften: «Jeg er lege, sa han enkelt ... og mengden vek til side» (fig 1). Denne annonsen ble også trykt opp som plakat og distribuert til leger over hele landet. I en fotnote i annonsen sto det: «Fritt etter Øvre Richter Frich» $(10,11)$.

Sitatet er altså brukt i flere sammenhenger og med litt forskjellig formulering. Hvor er så sitatet hentet fra? Var det Carling som i 1976 først formulerte det slik at det senere har versert som et sitat som ingen egentlig kjenner opphavet til?

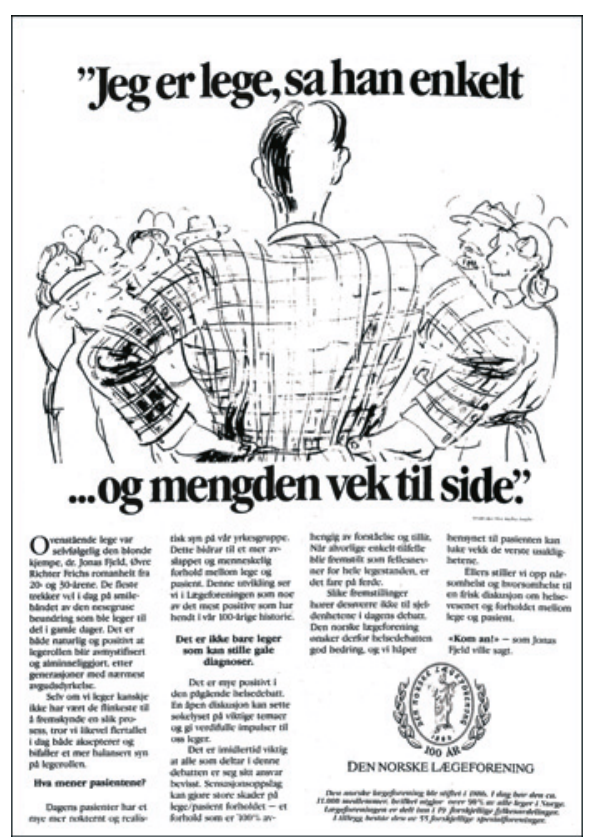

Figur 1 Da Den norske lægeforening markerte sitt 100-årsjubileum den første uken i juni 1986, hadde den en annonsekampanje i dagspressen der man spilte på et Jonas Fjeld-sitat (10,11) 


\section{Våre undersøkelser}

Vi ønsket å komme til bunns i dette mysteriet. Hvordan lyder det originale sitatet? Det finnes ikke i sitatordbøker (12-15).

Nasjonalbiblioteket har digitalisert 16 av de 21 Jonas Fjeld-bøkene. Disse er søkbare i fulltekst gjennom nettsiden bokhylla.no (1.4. 2013). Ved å søke på «Jeg er læge» får vi treff $i$ sju av bøkene. Flere steder presenterer han seg også som «norsk læge». Søkeordet «mengden» gir seks treff, men ingen av dem finnes i den formen som Willy Dahl gjengir det.

Ettersom det digitale biblioteket ikke er helt komplett, har vi lest de fem Jonas Fjeld-romanene som ikke er tilgjengelig via bokhylla.no: Hammerslaget (1917), Lucifers øie (1920), Jorden som drceper (1921), Nordlysets datter (1934) og Menneskejegerne (1935).

Det nærmeste vi har kommet, er en passasje i Lucifers øie (1920) (fig 2). Jonas Fjeld kommer forbi et åsted i London der en person ligger livløs i gaten, men folk stimler sammen og han når ikke frem i menneskemengden for å gi hjelp: «Fjeld banet sig vei gjennem den lille klynge. - Jeg er læge, sa han, og staar til tjeneste.» $(16$, s. $80-1)$.

\section{Sitat med eget liv}

Vår konklusjon er at den mest kjente versjonen av sitatet er en konstruksjon eller en sammenstilling av flere av Frichs beskrivelser av sin legehelt (tab 1). Betegnelsen «apokryft sitat» er antakelig en dekkende beskrivelse (8).

Vi synes at Willy Dahls variant er den beste: «Jeg er norsk læge, sa han enkelt, og mengden vek til side». Det er fordi den viser til fulle hvilken respekt folk hadde for den medisinske profesjonen, ved at de øyeblikkelig vek til side, selv om Fjeld sa det helt enkelt. Men det er et par interessante forskjeller mellom originalen i Lucifers øie og Willy Dahls versjon: Det var ikke slik at mengden vek til side i ærbødighet. Dr. Fjeld måtte brøyte seg frem. Dessuten presenterer han seg i originalen ved å stå til tjeneste det er altså den tjenestevillige, kanskje oppofrende, legen som viser seg, ikke den mer brautende typen, som man vel kan fornemme ut fra Dahl-sitatet.

Det er ingen klare fellestrekk ved de ulike situasjonene der Fjeld presenterer seg, og heller ikke slik at det naturlig utledes at en menneskemengde skulle vike til side. Hvorfor har da dette sitatet oppstått? Antakelig må det ha med omverdenens syn på legen å gjøre, på legerollen med dens antatte respekt og arroganse. Carlings tekst stammer i så måte fra en tid da skepsisen til legens autoritet var økende.

Det finnes en rekke apokryfe sitater i medisinen. «Sjelden kurere, ofte lindre,

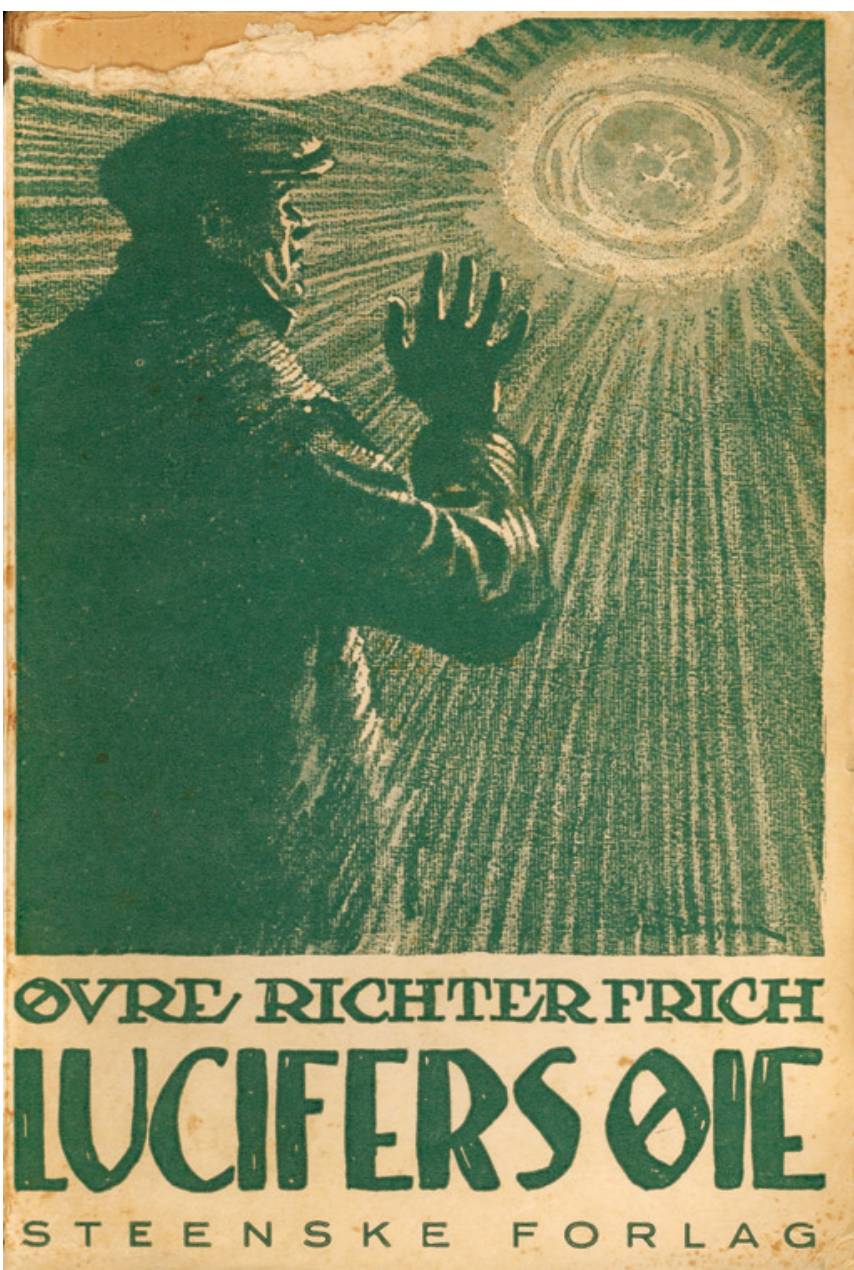

Figur 2 I Lucifers øie (1920), den 13. boken i serien om Jonas Fjeld, finnes sitatet: «Fjeld banet sig vei gjennem den lille klynge. - Jeg er læge, sa han, og staar til tjeneste.» Faksimile fra boken (16)

alltid trøste» og «primum non nocere»fremfor alt ikke skade - er de mest kjente (17). Opprinnelsen er uklar, men slike konstruerte sitater lever i beste velgående. Hvorfor har de fått leve så lenge? Antakelig fordi de er så bra at noen burde ha uttalt dem.

Helt ubeskjedent hevder vi at opplysningene om Jonas Fjeld-sitatet er et aldri så lite gjennombrudd i norsk medisin og i norsk lit- teraturhistorie. Sitatet er ikke helt slik vi har trodd og brukt det. Like fullt er historien om et av de mest kjente legesitatene i landet både verdifull og tankevekkende. Den viser hvordan sitater kan oppstå og leve sitt eget liv.

Vi takker Einar Skoglund for informasjon om Legeforeningens jubileum i 1986, og Willy Dahl for verdifulle opplysninger.
Tabell 1 Varianter av Jonas Fjeld-sitatet

\begin{tabular}{ll}
\hline Sitat & Kilde \\
$\begin{array}{l}\text { «jeld banet sig vei gjennem den lille klynge. } \\
\text { - Jeg er læge, sa han, og staar til tjeneste.» }\end{array}$ & Lucifers øie, 1920 (16) \\
«Jeg er norsk lege. Mit navn er doktor Jonas Fjeld.» & Carling, 1976 (4) \\
«Jeg er norsk læge, sa han enkelt, og mengden vek til side.» & Willy Dahl, personlig meddelelse, \\
& 1992 (5) \\
«Mitt navn er Jonas Fjeld. Jeg er norsk lege!» & Hals Gylseth, 1997 (9) \\
«Mitt navn er Jonas Fjeld. Jeg er lege!» & Hals Gylseth, 1997 (2) \\
\hline
\end{tabular}




\section{Ole Didrik Lærum (f. 1940)}

er professor (adj.) ved Københavns Universitet og professor emeritus ved Universitetet i Bergen. Forfatter har fylt ut ICMJE-skjemaet og oppgir ingen interessekonflikter.

\section{Ragnar Stien (f. 1938)}

er pensjonert nevrolog og samler av norsk kriminallitteratur.

Forfatter har fylt ut ICMJE-skjemaet og oppgir ingen interessekonflikter.

\section{Erlend Hem (f. 1970)}

er assisterende sjefredaktør i Tidsskrift for Den norske legeforening.

Forfatter har fylt ut ICMJE-skjemaet og oppgir ingen interessekonflikter.

\section{Litteratur}

1. Gylseth CH. Øvre Richter Frich. I: Norsk biografisk leksikon. http://nbl.snl.no/

\%C3\%98vre Richter Frich/utdypning (31.5.2013).

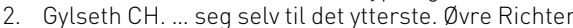
Frich og hans forfatterskap. Oslo: Cappelen, 1997: $12,24-30,114-28$

3. Dahl W. Dødens fortellere: den norske kriminalog spenningslitteraturens historie. Bergen: Eide, 1993: $62-7$.

4. Carling B. Norsk kriminallitteratur gjennom 150 år. Oslo: Gyldendal, 1976: 64-6, 73-5, 88-92, 129

5. Lærum OD. Legen som kunstner. I: Husebø S, red. Medisin: kunst eller vitenskap. Oslo: Ad Notam Gyldendal, 1992: 158-81.

6. Aabø S. Sylvia mot legemakta. Dagbladet 27.2.2008: 3. www.dagbladet.no/nyheter/2008/02/ 27/528122.html (31.5.2013)

7. Haug C. Hva er en lege? Tidsskr Nor Legeforen 2011; 131: 927.

8. Myhre JE. «Askepotterne blant landets embetsmænd» - legenes vei til samfunnstoppen

1811-1960. Michael Quarterly 2011; 8: 532-44. www.dnms.no/index.php?seks id $=137088 \& a=1$ (31.5.2013).

9. Gylseth CH. Forord. I: Frich ØR. De knyttede næver: en storforbryders roman. Oslo: Cappelen, 1997.

10. Annonsekampanje. Tidsskr Nor Lægeforen 1986; 106: 1872-3.

11. Stor festivitas. Tidsskr Nor Lægeforen 1986; 106 : 1342.

12. Roeim J, red. Den store sitatboken. Oslo: Ex libris, 1994.

13. Holmgård JB, red. All verdens sitater. Oslo: Aventura, 1995.

14. Jensen B, red. Ordspråkleksikon. Oslo: Schibsted, 1996.

15. Gundersen D, Evensberget S, red. Bevingede ord. 4. utg. Oslo: Kunnskapsforlaget, 2006

16. Frich $\emptyset \mathrm{R}$. Lucifers øie: en roman om lys. Kristiania: Helge Erichsen, 1920: 80-1.

17. Hem E. Tilbake til Hippokrates? Tidsskr Nor Lægeforen 2003; 123: 3577-8.

Mottatt 5.7. 2013, første revisjon innsendt 7.10. 2013, godkjent 17.10. 2013. En av forfatterne er redaktør i Tidsskriftet. Manuskriptet er derfor behandlet eksternt av en uavhengig redaktør. Redaktør: Magne Nylenna. 